\title{
Introduction: a normative or pragmatic definition of NGOs?
}

\section{Christine Bakker and Luisa Vierucci}

\section{NGOS AND MAINSTREAM INTERNATIONAL LAW}

It is today beyond doubt that Non-Governmental Organizations (NGOs) play a prominent role in international law-relevant fields, from treaty making to rule implementation; from support to courts to aid delivery. However, the increasingly active stance of these organizations on the international plane still raises questions concerning their position under international law, which is the subject of a continuing debate amongst legal scholars. In the last decade this debate has focused especially on the question whether NGOs have international legal personality.

In legal doctrine an entity with international legal personality is usually described as an entity endowed with legal rights and/or obligations and legal capacities directly conferred on it under international law. Sometimes the legal capacities are specified as including procedural capacity and/or treaty-making capacity. While states clearly enjoy all aspects of international legal personality, this is not necessarily the case for other entities. For instance whereas International Governmental Organizations (IGOs) usually have treaty-making capacities, they cannot invoke the contentious jurisdiction of the International Court of Justice (ICJ) or of regional human rights courts. Legal scholars have not reached a consensus on the question whether NGOs also enjoy (some components of) international legal personality. Moreover some authors have examined the legal status of NGOs, rather than their legal personality. The term 'legal status' has been efficaciously defined as 'a broad concept, which embraces all kinds of provisions and practices which explicitly take account of NGOs or which can be used by these organizations for acting in the international legal context, irrespective of which field of international law the material belongs to'. ${ }^{1}$ The content of this status may vary according to the circumstances and needs to be specified for each particular entity.

1 Anna-Karin Lindblom (2005), Non-Governmental Organisations in International Law, Cambridge: Cambridge University Press, p 116. 
This approach appears to be particularly fitting to NGOs, since it encompasses the components of the traditional concept of international legal personality, while at the same time admitting that other elements or practices may define their international legal position. Nevertheless, as the following overview will demonstrate, most legal scholars continue to address the international legal position of NGOs in terms of 'legal personality' or of 'subjects' under international law.

Four main standpoints can be distinguished in international legal literature representing, as it were, a gliding scale in the recognition of NGOs as international legal subjects.

\section{Reluctance to Accept International Legal Personality of NGOs}

On one side of the spectrum there is strong reluctance to attach any international legal consequences to the existence and activities of NGOs. While some scholars expressly deny that such organizations can have any legal position in the international sphere, ${ }^{2}$ others do not mention this possibility at all in their discussion of the subjects of international law. ${ }^{3}$ This attitude is in line with the traditional conception of international law, according to which the subjects of international law are narrowly defined as comprising states, international organizations and a few historic legal subjects, such as the Holy See and, according to some, the Sovereign Order of Malta.

This stand reflects a positivist approach to international law, having its roots in the Westphalia inter-state system. As is well known, however, the ICJ had dismissed the position that states are the only subjects of international law as early as 1949 in its advisory opinion concerning the Reparations for Injuries case. The Court was asked to clarify whether the United Nations, as an organization, had the capacity to bring an international claim against a government regarding injuries that had been caused to the organization by that state. On the question of international legal personality, in an obiter dictum the Court held that 'The subjects of law in any legal system are not necessarily identical in their nature or in the extent of their rights and their nature depends upon the needs of the community.' 4

2 S. Sur (1999), 'Vers une Cour pénale internationale: la Convention de Rome entre les ONG et le Conseil de securité', Revue Générale de Droit InternationalPublic, 103(29), 35-8.

3 Cf. Ian Brownlie (1966), Principles of Public International Law, Oxford: Oxford University Press, 5th edn, 1998, pp. 57-61; Jean Combacau and Serge Sur (2006), Droit International Public, Paris: Montchrestien, 7th edn, pp. 309-25.

4 Reparations for Injuries Suffered in the Service of the United Nations, ICJ Reports, 1949, p. 178. 
Even though this opinion concerned IGOs, the Court clearly laid down the more general principle that also other entities than states can have international legal personality. It is therefore somewhat surprising that some scholars continue to be reluctant to accept the possibility that non-state actors, other than IGOs, may also be regarded as subjects of international law.

Admittedly, to date no clear pattern of rules has evolved which determine the legal personality of NGOs as a 'category', their rights and obligations under international law or their legal standing before international courts and tribunals. On the other hand it cannot be denied that certain NGOs have explicitly acquired legal personality, either by entering into agreements with IGOs or as a result of specific treaty provisions. ${ }^{5}$ Moreover one could argue that the reality of increasing involvement of NGOs in the international context requires some form of legal recognition of these organizations and possibly legal regulation as well.

\section{Open Attitude towards NGOs as Subjects of International Law}

At the other end of the spectrum, a number of authors have instead adopted an open attitude towards recognizing NGOs as international legal subjects. Those authors argue that following 'a more "liberal" delimitation of subjects of international law' could lead to the conclusion that 'an entity can be considered a subject of the international legal system if it has rights and/or obligations under that system'. ${ }^{6}$ A clear example thereof is the direct endowment of certain rights and responsibilities to the International Committee of the Red Cross by the four Geneva Conventions of 1949. ${ }^{7}$

A variety of legal arguments have been put forward to support an open Cross.

This is in particular the case of the International Committee of the Red

A. Reinisch (2005), 'The changing international legal framework for dealing with non-state actors', in Philip Alston (ed.), Non-State Actors and Human Rights, Oxford: Oxford University Press, pp. 37-89, at 70.

7 See Articles 9 and 10 of the First, Second and Third Geneva Conventions; Articles 10 and 11 of the Fourth Geneva Convention. On this point see Ch. Dominicé (1994) 'La personnalité juridique internationale du CICR', in Christophe Swinarski et al. (eds), Etudes et essais sur le droit international humanitaire et sur les principes de la Croix-Rouge en l'honneur de Jean Pictet, Geneva: CICR and The Hague: Nijhoff, pp. 663-73, and P. Reuter, 'La personnalité juridique internationale du Comité International de la Croix-Rouge', ibid., pp. 783-91. They both conclude for the international personality of the International Committee of the Red Cross not only on the basis of the Geneva Conventions but through the analysis of practice (the Committee entertains quasi-diplomatic relations with States, enjoys immunities typical of intergovernmental organizations and enters into agreements with states). 
attitude towards NGOs under international law. Some legal scholars ${ }^{8}$ have affirmed that, especially in the human rights field, international rights and obligations are not only conferred on states, but also on individuals and other non-state actors. This view is increasingly adopted by international human rights monitoring bodies. ${ }^{9}$ For example, the UN Human Rights Committee first affirmed in 2000 the binding nature of the core of human rights obligations for all members of society, including NGOs. ${ }^{10}$

Other scholars have upheld that NGOs inevitably play a role in the modern, democratic law-making process, which is no longer exclusively reserved for states, beyond the human rights area. ${ }^{11}$ According to this view, non-state actors directly participate in the formation of so-called 'media-law' which is created alongside 'state-law' that is built through traditional channels. ${ }^{12}$ By 'media-law' Reisman refers to the process through which NGOs, together with political and social pressure groups as well as individual commentators, directly contribute to the continuous process of rule creation, which is communicated through the media. With this assertion Reisman seems to imply that NGOs have already gained some degree of de facto international legal personality (at least in terms of law making), without the need of any formalization of that capacity. Although such an approach highlights the complexity of normative developments under modern international law, it may be questioned whether the abovementioned category of 'media-law' meets the criteria for genuine law making in terms of accountability, representation and clarity. Therefore, the assertion that NGOs play a key role in the formation of international law is somewhat weakened by limiting this role to a process which could also be considered as merely 'normative pressure' exercised by civil society.

Finally, some scholars go so far as to question the appropriateness of the

8 In particular Reinisch, supra note 6 , at 71 , stresses this point by referring to art. 30 of the Universal Declaration of Human Rights, UN G.A. Res. 217 (1948), Article 30: 'Nothing in this Declaration may be interpreted as implying for any State, group or person any right to engage in any activity or to perform any act aimed at the destruction of any of the rights and freedoms set forth herein.'

9 Reinisch, supra note 6, at 69-72. On this point see extensively Andrew Clapham (2006), Human Rights Obligations of Non-State Actors, Oxford: Oxford University Press.

10 UN Committee on Economic, Social and Cultural Rights, General comment No. 14 of 11 August 2000, U.N. Doc. E/C.12/2000/4, para. 42 .

11 M. Reisman (2005), 'The democratization of contemporary international lawmaking processes and the differentiation of their application', in Rudinger Wolfrum and Roeben Volker (eds), Developments of International Law in Treaty Making, Heidelberg: Springer, pp. 19-20.

12 Ibid., pp. 24-6. 
traditional view that there exist only 'subjects' and 'objects' of international law; subjects being those elements bearing, without the need for municipal intervention, rights and responsibilities, and objects being the rest. ${ }^{13}$ In particular, one authoritative scholar, Rosalyn Higgins, has proposed to regard international law as a dynamic decision-making process in which a variety of actors take part with the objective of maximizing certain values. Instead of 'subjects' and 'objects' in this model there are only participants. Along with states, international organizations, multinational corporations and individuals also NGOs would then be considered as participants in the international legal order. ${ }^{14}$ Similarly, another commentator has held that 'the intensely debated but largely sterile question as to whether or not NGOs [. . .] have emerged as new subjects within the international legal order' can be avoided by using a constitutional or functional approach to international law. ${ }^{15}$ According to this approach, NGOs can be "elegantly integrated into a broader concept of "international community" , 16 if one would consider that NGOs make the public opinion and public conscience of a cosmopolitan civil society heard in international relations.

Despite the differences among these views, the fundamentally favourable approach towards recognizing the role of NGOs in the international legal order does attempt to come to terms with the ever-increasing proliferation of actors at the international level. Such an open attitude has the advantage of clarifying the status of these non-state actors which are currently operating, at least to some extent, in a legal vacuum.

\section{Cautious Recognition of NGOs' Legal Personality under International Law}

Two positions cover the middle ground of the aforementioned conceptual scale. Firstly, some scholars favour a cautious recognition of legal personality for NGOs, albeit within the traditional international legal framework. ${ }^{17}$ While

13 Rosalyn Higgins (1994), Problems and Process; International Law and How We Use It, Oxford: Clarendon Press, p. 49.

14 Ibid., p. 50.

15 D. Thuerer (1999), 'The emergence of non-governmental organizations and transnational enterprises in international law and the changing role of the State', in Rainer Hofmann (ed.), Non-State Actors as New Subjects of International Law, Berlin: Duncker \& Humblot, p. 53.

16 Ibid., p. 53.

17 R. Falk (1995), 'The world order between inter-state law and the law of humanity', in Daniele Archibugi and David Held (eds), Cosmopolitan Democracy; An Agenda for a New World Order, Cambridge: Polity Press, pp. 163-79; Christian Tomuschat (2003), Human Rights: Between Idealism and Realism, Oxford: Oxford University Press, p. 231. 
stressing that states continue to be the principal subjects of international law, even though the central role of the state is eroding, ${ }^{18}$ these commentators acknowledge that non-state actors, including NGOs, are playing such an important role in overall governance structures that they have become part of the international legal order.

It has been argued that such a cautiously favourable approach is also reflected in the final Articles on Responsibility of States for Internationally Wrongful Acts, ${ }^{19}$ adopted by the International Law Commission in 2001. ${ }^{20}$ Article 33(2) stipulates that the part of the Articles dealing with state responsibility 'is without prejudice to any right, arising from the international responsibility of a State, which may accrue directly to any person or entity other than a State'. Although the legal personality of non-state actors is not expressly afforded by this provision, according to the Commentary to the Articles such a development may not be excluded in the future. ${ }^{21}$

The second attitude consists in a more flexible recognition of the role played by NGOs in the international legal order without attempting to place them in a fixed legal framework. ${ }^{22}$ According to this view, legal rights and responsibilities should be accorded to NGOs on a case-by-case basis, and only if this is 'functional' to the pursued objective. ${ }^{23}$ The rationale behind the functionality requirement is that, in the current situation, NGOs effectively participate in various fields of international concern, despite the limited legal regulation of such participation. It is therefore not necessary, according to this reasoning, to endow all NGOs with international legal personality, or to treat NGOs as such as a new

18 Falk, supra note 17, pp. 166-7. Falk distinguishes, however, between fields in which inter-state realities persist, and where inter-state law provides for control (for example, war/peace, environmental issues, transnational economic activity) and fields in which non-state actors are gaining an increasingly important role, and where they already contribute to the formation of the 'law of humanity', a development which he strongly supports; ibid., p. 167.

19 UN Doc. A/56/10 (2001).

20 P. Alston (2005), 'The 'not-a cat' syndrome: can the International Human Rights regime accommodate non-state actors?' in Philip Alston (ed.), supra note 6, at 24.

21 The Commentary to the Articles states that they do not deal with the possibility of the invocation of responsibility by non-state actors but at the same time it notes that some procedures may be available enabling a non-state entity 'to invoke the responsibility on its own account and without State involvement', Report of the International Law Commission to the General Assembly, Supplement No. 10 (A/56/10), Commentary to Article 33, at 234-5.

22 R. Wedgwood (1999), 'Legal personality and the role of non-governmental organizations and non-state political entities in the United Nations system', in Rainer Hofmann (ed.), supra note 15, at 21-36.

23 Ibid., at 36. 
category of subjects of international law. ${ }^{24}$ The proponents of such a view further argue that the question of subjects of international law should be approached in an undogmatic way. For example, Thuerer states that "[w]e should use a functional approach according to the Roman proverb "ubi societas, ibi ius" and conclude what the law is from social forces'. ${ }^{25}$ According to Wedgwood, 'the interesting inquiry, each time, is whether according rights of participation and address, or imposing some form of direct responsibility for non-state actors in the international community, will usefully increase the capacity to resolve conflicts and enforce standards of human security'. ${ }^{26}$ In her view, the role of NGOs has been seen as beneficial and creative, subject to suitable cautions.

The functional approach combines the recognition of the role of NGOs with some flexibility in terms of legal regulation, taking account of the diversity of actors and the complexity of decision-making processes at the international level. The inconvenience of such a flexible, case-by-case approach could be the uncertainty of all actors involved in when and how an NGO may be awarded rights and obligations under international law, or when and how an NGO could be held internationally accountable for its actions.

These various approaches clearly demonstrate the existence of a recurrent dilemma haunting modern international law: on the one hand, the perceived benefits of regulating an existing and progressing practice of NGO involvement in the international legal order; and, on the other hand, the perceived risks of legalizing the participation of these non-state actors in the traditional, state-dominated system.

\section{OBJECTIVE AND SCOPE OF THE VOLUME}

The diversity of views among academics, which has been sketched above concerning the international legal position of NGOs, called for the collection of empirical data on the part of NGOs themselves in order to complete the picture. This was the starting point of the project which was the foundation of the present volume. In 2002, a workshop was convened at the European University Institute, bringing together representatives of various NGOs and specialists in public international law; that is, both practitioners and scholars. The workshop aimed to address the issue of the status of NGOs in modern international law, by focusing in particular on the modalities of NGOs' cooperation with IGOs and international courts or quasi-judicial bodies.

\footnotetext{
24 Thuerer, supra note 15 , at 91.

25 Ibid., at 91.

26 Wedgwood, supra note 22, at 36.
} 
The workshop consisted of two parts. First, NGOs' representatives presented the modalities of their organization's cooperation with IGOs and international (quasi-)judicial bodies, commenting on the degree of legal formalization of such cooperation. With a view to steering the debate towards a qualitative assessment of the existing cooperation mechanisms, participants were asked to make their presentations by answering a questionnaire which had been distributed in advance (see Appendix 1). The questions were designed to withdraw the veil over practitioners' perception of the status of their respective organizations, with a view to comparing the 'formal picture' of NGOs under international law to their real functioning in practice. ${ }^{27}$ The second part of the workshop hinged upon the legal status of NGOs from a more theoretical perspective, leading to a debate sparked by the answers provided by the practitioners.

Throughout the workshop, a clear distinction was made between, on the one hand, cooperation between NGOs and IGOs and, on the other hand, the interaction between NGOs and international courts and quasi-judicial bodies. The main results of the NGOs' practice concerned the variety of forms taken by their relationship with IGOs, ranging from formal participatory rights or consultative status to informal contacts with individual IGOs' officials. Indeed, the informal relationship appeared to be quite effective and appreciated by the great majority of NGOs.

On the other hand, the possibilities for cooperation between NGOs and international tribunals or (quasi-)judicial compliance mechanisms appeared to be more limited, the most important modalities being amicus curiae intervention and, in some cases, provision for locus standi before international bodies. Participants in the workshop pointed to the need for further regulation in this field, in particular for amicus curiae intervention, in order to better protect the rights of the defence in criminal trials or the position of the applicant in other types of international proceedings, and to ensure the legitimacy of the NGO presenting an amicus brief.

Given these differences, the same subject-matter division has been maintained in this book which has been built upon the main findings coming out of the workshop. The present volume aims to provide some preliminary answers to the following question: is there a need for a revised legal status for NGOs in international law? In other words, does the increasing international role that NGOs de facto play require a reconsideration of their de jure position or, on the contrary, does the flexibility currently enjoyed by NGOs constitute the most effective and desirable solution for all international actors involved?

27 The questionnaire was mainly elaborated by Anna-Karin Lindblom, now in charge of the human rights division of the Swedish Ministry of Foreign Affairs, who is the author of Non-Governmental Organisations in International Law supra note 1. 
In order to answer such questions, the first part of the book addresses issues connected with the relationship between NGOs and IGOs. It provides an empirical analysis of the various legal positions which formally define the scope of NGO activity within different IGOs, in particular within the United Nations system, but also the European Union.

Emanuele Rebasti first examines the different forms of cooperation between NGOs and IGOs, ranging from consultative status to purely informal bilateral contacts and then evaluates whether legal formalization has so far provided an effective framework for cooperation between IGOs and NGOs. The chapter shows that, while there clearly is a gap between the concrete dynamics of the interplay between NGOs and IGOs and the legal definition of this relationship, it is much debated whether the emerging paradigm of $\mathrm{NGO/IGO} \mathrm{relations} \mathrm{should} \mathrm{be} \mathrm{crystallized} \mathrm{in} \mathrm{a} \mathrm{new} \mathrm{legal} \mathrm{regime} \mathrm{or} \mathrm{rather} \mathrm{left}$ to self-regulation. The author argues that the two opposing approaches will finally combine to provide tailored solutions to the problems raised by civil society's enhanced participation in IGO activities. He analyses the reforms recently introduced or proposed by a number of intergovernmental organizations, such as membership of NGOs in the African Union, ECOSOC; extended NGO participation in UN organs; streamlined and depoliticized accreditation procedures within the UN; renewed self-regulation and self-organization of NGOs in their relations with the UN; an innovating participatory status for NGOs in the Council of Europe; and informal participation and administrative facilitation for NGOs at the EU. Three models of interaction are identified, responding to the needs raised by the nature of the contribution NGOs seek to make to the intergovernmental process, by the field of action in which NGOs' participation takes place, and by the specificity of the intergovernmental organization at stake. Finally the author opens new avenues for exploration by shifting the question of the legal status of NGOs in international law from a legal personality perspective to the functioning of IGOs. In this light, civil society participation is increasingly perceived as a parameter of IGOs' good governance.

In the second contribution, Olivier de Frouville takes a closer look at the emergence of what he calls a 'servile society', namely NGOs who serve a state rather than public interest. He analyses the relationship between the United Nations and an increasing number of government-oriented NGOs or 'GONGOs', who claim to represent independently the civil society of their country, while in reality maintaining close links with the national government and pursuing the interests and policies of the latter. Some examples of GONGOs are represented by Chinese 'mass'-organizations, which openly admit a link with the government, but also by civil society organizations pursuing a certain goal which at the same time constitutes a foreign policy priority of the government of their country such as Islamic organizations 
actively following the situation of Kashmir, and pursuing the same objective as the Pakistani government. The author strongly criticizes the way in which various United Nations bodies, in particular the Human Rights Commission and ECOSOC, have established a more or less formalized relationship with these organizations, and proposes some measures to improve this situation. It remains to be seen if and how the newly established Human Rights Council will be willing and able to address the above shortcomings.

Valentina Bettin examines the evolution of the role and legal status of NGOs in the framework of the European Union Development Policy. The author takes into consideration the relationship between the EU and NGOs in both the implementation and the formulation of development policy. She demonstrates that the cooperation between NGOs and the EU is well advanced as regards the implementation of development policy, through the formula of co-financing. However, the analysis also reveals a tension between the formalization and non-formalization of the NGO involvement in development policy. Such a tension does not exist in the framework of the Cotonou Agreement, which regulates the development cooperation between the African, Caribbean and Pacific states (ACP states) and the EU. This agreement requires consultation with NGOs on the formulation of development policies and strategies. The author concludes that the formalization of NGO consultation in the context of the relationship between the EC and the ACP states has been possible because the formal NGO involvement affects an international institutional framework and not the internal decision making of the European Union. In other areas of development cooperation, as well as in the other sectors covered by the EC Treaty, the Commission has been reluctant to formalize the relations with NGOs. As a result, NGO involvement in the EU and its policies mainly takes place on an informal basis.

Attila Tanzi concludes the first part of the volume by presenting his findings on the participation and status of NGOs in the field of international environmental law. After examining the international instruments on sustainable development, in particular the Aarhus Convention, he underscores the recent shift of emphasis in the role of NGOs in the environmental process, from decision making to the implementation phase. He concludes that, while public participation through NGOs is fairly well established in national environmental law processes, such participation is significantly weaker at the international level. The case-by-case approach followed in the various international environmental fora, such as the UN, the UNECE Pan-European Framework and the mechanisms envisaged by the Aarhus Convention, is inherent in the scattered setting of the international environmental institutions. According to Tanzi, both states and NGOs seem to have, for opposite reasons, a strong interest in avoiding formal regulation of public participation in international fora.

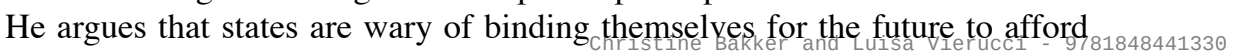


certain rights of public participation across the board, even though they have accepted such participation in a specific context. For their part, NGOs appear not to be interested in having a fixed legal framework either, since this may limit their participation in international environmental fora. In a less regulated context, NGOs may be able to increase their participation on a case-by-case basis.

Taken together, these contributions demonstrate that there is a clear need to rethink the traditional forms of cooperation between NGOs and IGOs. Nevertheless, the question whether a new legal regime is also required is controversial. Indeed, it appears as if a certain degree of informality (hence flexibility) in the relationships between these two types of organizations is rather appreciated by NGOs and IGOs alike, albeit for different reasons.

The second part of the book addresses forms of participation and standing of NGOs before international courts and quasi-judicial bodies. The first contribution, by Luisa Vierucci, examines the status of NGOs before international courts and tribunals, in particular the regional systems of human rights protection, international criminal tribunals and the WTO dispute settlement mechanism. It attempts to assess whether NGOs are satisfied with the access to justice they are currently experiencing, and whether it is desirable to suggest changes de lege ferenda in order to make their participation in international justice more effective. Distinguishing between direct (locus standi) and indirect (amicus curiae intervention) participation, the author first sets out, for each of these two modalities, the international courts and bodies to which NGOs have access according to their respective rules. Subsequently, she presents and comments on the desirability of further regulation of NGOs participation, analysing the advantages and disadvantages of increased formalization. In particular the author identifies two conflicting interests that must be weighed: on the one side, the need to ensure that those issues that can be put forward or properly dealt with only by NGOs have an avenue for presentation before the international judge; on the other, the necessity to limit the risks that uncontrolled participation of NGOs may constitute for the rights of the parties to the case. Considering the importance of these different interests, the difficulties in finding a balance between them, and the formalism that is inherent in the very nature of international proceedings, it is concluded that a more formalized legal status for NGOs' participation, whether direct or indirect, in international adjudication seems unavoidable. The author presents arguments in favour of both informal and formal regulation of the participation modalities, and formulates some ideas on how to address two major concerns related to NGOs' participation before international courts and tribunals, namely representation issues, and safeguarding the rights of the parties.

Cesare Pitea next addresses the participation of NGOs in compliance review procedures in the environmental field, By way of a case study, the 
analysis focuses on the key role played by NGOs in the compliance review procedure under the Aarhus Convention. The author notes that, despite some positive experiences, the governmental view still prevails according to which NGOs' participation, in particular their power to initiate compliance review procedures, may undermine the non-confrontational functioning of those procedures. However, he concludes that the positive impact of the formal involvement of NGOs within compliance review mechanisms in terms of increased efficiency and transparency is becoming evident. He finally points to some possible further developments in terms of regulation of NGO participation.

Thus, the analysis in this second part of the volume indicates that increased regulation, be it formal or informal, would be appropriate, both in terms of NGOs' direct (locus standi or access to compliance committees) and of indirect (amicus curiae) participation. It also demonstrates that the level of formal regulation is a function of the degree of participation. The ideas put forward in the separate contributions on possible modalities of such regulation will certainly contribute to the discussion among legal scholars and practitioners on the creation of a new legal regime for increased international involvement of NGOs in international legal proceedings.

Drawing on the various contributions, Pierre-Marie Dupuy derives some conclusions on the desirability of further regulation of the status of NGOs, considering, inter alia, whether, in the international legal order as it is currently evolving, maintaining a certain degree of flexibility in the relationships between some of its increasingly influential actors or participants may be more beneficial and efficient for the achievement of its fundamental goals.

\section{DEFINING THE INDEFINABLE: NGOS IN INTERNATIONAL LAW}

Although legal scholars have already been debating the issue, it is surprising that lengthy discussions can be held and elaborate papers can be written about NGOs and their legal status, without defining the term 'Non-Governmental Organization' itself. Neither at the EUI workshop, nor in the contributions to this book, has the need to determine such a definition been prominently brought to the fore.

Even in the absence of an agreed normative definition, both experts and the public at large constantly use the term, confident that others know what they are talking about. One could therefore wonder whether it is necessary at all to determine a generally accepted definition. In other words: should the flexibility which seems to be desired by all actors in the relationships between NGOs and IGOs be maintained with regard to the definition of such organizations as well? 
In order to address this question, a brief look will first be given to the attempts which have been made to define the term ' $\mathrm{NGO}^{\prime}$ in international legal literature, as well as the different definitions adopted by various IGOs. After examining some negative consequences of the 'normative loophole', the specific situation of NGOs before international courts and tribunals will once again be addressed, in order to establish whether a normative definition would be required.

\section{Inexistence of an Agreed Definition in International Law}

Although the term 'NGO' appears in an increasing number of international legal instruments and so-called 'soft-law' instruments, only a few of them include a definition of this type of organization. Moreover the few existing definitions show some important differences. For example, the term 'nongovernmental organization' is included in Article 71 of the UN Charter, but no definition was provided. ${ }^{28} \mathrm{~A}$ definition was subsequently established by ECOSOC in 1950, according to which, for the purposes of consultative arrangements, an NGO is understood as '[a]ny international organization which is not created by intergovernmental agreement' ${ }^{29}$ A more elaborated definition was adopted in $1996,{ }^{30}$ and a number of conditions were enumerated for the establishment of consultative relations with an NGO. These conditions include that the aims of an NGO shall be in conformity with the spirit, purposes and principles of the UN Charter; that it has a democratically adopted constitution as well as a representative structure with appropriate mechanisms of accountability; and that it shall be of recognized standing within the particular field of its competence or of a representative character. ${ }^{31}$ The relevant ECOSOC resolution refers neither to a non-profit making aim nor to a national legal personality.

Within the Council of Europe, consultative relationships with NGOs have

28 According to this provision, 'The Economic and Social Council may make suitable arrangements for consultation with non-governmental organizations which are concerned with matters within its competence.'

$29 \mathrm{E} / \mathrm{RES} / 288(\mathrm{X})$, Review of consultative arrangements with non-governmental organizations, 27 February 1959, para. 8.

30 'Any such organization that is not established by a governmental entity or intergovernmental agreement shall be considered a non-governmental organization for the purpose of these arrangements, including organizations that accept members designated by governmental authorities, provided that such membership does not interfere with the free expression of views of the organization', E/RES/1996/31, Consultative relationship between the United Nations and non-governmental organizations, 25 July 1996, para. 12.

31 Ibid., para. 2 and paras 9-12. 
been established since $1951,{ }^{32}$ although no definition of such organizations had been adopted at that time. However the 1986 Convention on the Recognition of the Legal Personality of International Non-Governmental Organisations ${ }^{33}$ does provide several elements of a definition of NGOs. It enumerates some conditions which 'associations, foundations and other private institutions (hereinafter referred to as NGOs)' must satisfy. Contrary to the 1996 ECOSOC resolution, these conditions include the requirement of a non-profit aim, which must also be of 'international utility'. The explanatory report to the Convention indicates that a trade union is an NGO, while a commercial organization is not. ${ }^{34}$

Finally, in 1999, the Organization of American States (OAS) adopted new Guidelines for Participation by Civil Society Organizations in OAS activities ${ }^{35}$ which define civil society organizations as 'any national or international institution, organization or entity made up of natural or juridical persons of a private nature'. This definition is broader than the one previously adopted, which was limited to an organization made up of natural or juridical persons of a private nature.

Given the absence of a universal definition of NGOs in the primary sources of international law, several attempts have been made in legal doctrine to define the seemingly indefinable category. Although the proposed solutions often indicate what NGOs are not, ${ }^{36}$ some authors have tried to single out those elements which identify such an organization. Thuerer seems to accept the legal definition provided by Macalister-Smith, whereby NGOs (i) are not established by a government, or by an intergovernmental agreement; (2) are typically private institutions: associations, foundations, federations or other unions founded on the basis and under the regime of the private law of a state;

32 Council of Europe Resolution (51)30F, Relations with International Organisations, both Intergovernmental and Non-Governmental, 3 May 1951.

33 Council of Europe, European Convention on the Recognition of the Legal Personality of International Non-Governmental Organisations, ETS No. 124, entered into force on 1 January 1991.

34 Explanatory Report on the European Convention on the Recognition of the Legal Personality of International Non-Governmental Organisations, Strasbourg, 1986, commentary on art. 15 of the Convention, http://www.uia.org/legal/ app411.php\#bn1a, accessed 4 January 2007.

35 CP/RES. 759 (1217/99), Guidelines for Participation by Civil Society Organisations in OAS Activities, 15 December 1999.

36 For example, NGOs are not established or controlled by states, they do not seek to overthrow governments by force, they do not aim to acquire state power, they do not seek financial profit for their own sake; see M. Kamminga (2005), 'The evolving status of NGOs under international law: a threat to the inter-state system?', in Philip Alston (ed.), supra note 6, at 96. 
and (3) have concerns, purposes and objects which are, in contrast to the origins of NGOs, of a public nature. ${ }^{37}$ Kamminga points out that 'NGOs are usually thought of as having an international character, with members and branches in more than one country and with objectives that are not limited to one State. ${ }^{38}$ All these elements are also mentioned by Reinisch, who further adds the requirements of a minimal organizational structure, and of established headquarters. ${ }^{39}$ Lindblom distinguishes between NGOs with an international character and those of a purely national nature. She also considers that an NGO does not use violence for promoting its interests, that its internal structure must be democratic, and that it normally, but not necessarily, enjoys legal personality under national law. ${ }^{40}$

Even though these definitions do not differ dramatically, the fact that not all the mentioned requirements are taken up by every commentator demonstrates that to date no consensus has been reached among legal scholars on an exact definition of NGOs. ${ }^{41}$

\section{Negative Consequences of the Normative Loophole}

Whereas the non-existence of a clear and common definition of NGOs may have some benefits in terms of flexibility, some negative consequences should also be highlighted. In the first place, the abovementioned GONGO phenomenon is a direct effect of what could be regarded as a normative loophole. Despite their lack of independence from national governments, GONGOs may benefit from the arrangements existing within the UN system and destined for genuine non-governmental organizations. In reality, those organizations pursue policy or political goals of the state where they are registered; they are sometimes state-controlled and they often lack adequate accountability mechanisms. As demonstrated by Olivier de Frouville in his contribution to this volume, the relationships established between GONGOs and IGOs are based on a broader definition of NGOs than those discussed in the previous paragraphs. Their involvement in the work of the UN and other IGOs, and even their participation in NGO platforms regrouping several NGOs pursuing

37 Thuerer, supra note 15 , at 43.

38 Kamminga, supra note 36 , at 97.

39 Reinisch, supra note 6 , at 40 , note 19.

40 Lindblom, supra note $1,48 \mathrm{ff}$.

41 Kamminga notes that a broad definition of NGOs, such as the one adopted by H. Rechenberg (1997) 'Non-Governmental Organizations', in Rudolph Bernhardt (ed.), Encyclopaedia of Public International Law, vol. 3, Amsterdam: North-Holland, at 612, may encompass multinational corporations and even national liberation movements; supra note 36 , at 95. 
certain common aims, may negatively affect the functioning and impact of genuine NGOs. Indeed, one of the main strengths of NGOs is precisely their independence from governments, which allows them to provide information, to carry out analyses and to formulate positions in their fields of expertise without any political bias, or at least in disregard of state interests.

The lack of clarity about the type of organizations that may legitimately be considered as NGOs also leads to legal uncertainty in cases where NGOs are granted certain rights. The question is then which organizations may benefit from such rights and which may not. Such uncertainty may arise particularly with regard to their participation before international courts and tribunals. For example, when NGOs have locus standi before a regional or international judicial body, can any organization considering itself as non-governmental bring a case before that body and act as a party in the proceedings? Or, on the other hand, should certain standards be set ensuring, for instance, a minimum degree of representation? Similar questions can be asked concerning indirect participation before international tribunals. Should each and every NGO be permitted to present amicus curiae briefs to these judicial bodies in all circumstances? These points are addressed in detail in the contribution of Luisa Vierucci.

It is, however, clear from the outset that, depending on the definition of the term 'NGO', participatory rights of civil society organizations may be dramatically expanded or curtailed. In other words, each element of a possible definition will undoubtedly exclude certain organizations and bar them from access to international courts. On the other hand, the formal nature of (international) judicial proceedings and well established international rules regarding the rights of the defendant require a certain regulation with respect to the parties before international tribunals. Moreover, unlimited participatory rights for all types of NGOs would further increase the already important workload of these judicial bodies, ultimately leading to reducing access to justice altogether.

It would therefore seem that a certain form of regulation is indeed required with respect to the participatory rights of NGOs before international tribunals. On the other hand, in the broader context of flexibility as regards the relationships of NGOs with IGOs, and taking account of the wide variety of NGOs and the interests they support, it might 'by definition' be impossible to formulate a uniform definition. However, is it really necessary to have an agreed universal definition, or would it not be sufficient to agree on a generally accepted list of minimum requirements for an organization to qualify for the category 'NGO'? As the various contributions to this volume demonstrate, the nature of the phenomenon of NGOs itself, as it has evolved in practice, does not allow for excessive formalization. Moreover there appears to be circularity in the effort to define NGOs. In practice, a wide range of organizations hags ${ }_{81848441330}$ 
evolved, their diversity stemming from the very absence of prior regulation. As a result, it is extremely difficult (possibly not workable) to find common features making it possible to mould all these elements into one definition.

The solution may lie in a dual approach, maintaining flexibility in both the legal status and the definition of NGOs for their relationships with IGOs in general, while at the same time introducing some degree of regulation of NGOs for their participation before international (quasi-)judicial bodies. Flexibility may indeed be the best recipe for efficiency in the role of NGOs in the international legal order. However, such a flexible attitude should nonetheless allow for a minimum of formalization in the judicial field. 
Christine Bakker and Luisa Vierucci - 9781848441330 Downloaded from PubFactory at 04/26/2023 07:12:26AM 